\title{
ANALISIS KANDUNGAN NUTRISI PADA PAKAN DENGAN FEED ADDITIVE RESIDU EKSTRAKSI KULIT MANGGIS (Garcinia Mangostana L.)
}

\author{
Heru Sasongko $^{1 *}$, Yeni Farida ${ }^{1}$,Nur Indriana Kusumastuti ${ }^{2}$, Gea Ros Alifa ${ }^{2}$, Sutanto $^{3}$ \\ ${ }^{1}$ Program Studi Farmasi FMIPA Universitas Sebelas Maret, \\ ${ }^{2}$ Program Studi D3 Farmasi FMIPA Universitas Sebelas Maret, \\ ${ }^{3}$ Program Studi Matematika FMIPA Universitas Sebelas Maret, \\ Jl.Ir Sutami No 36A kentingan Surakarta 57126 Jawa Tengah \\ *Penulis Korespondensi: heru_sasongko@staff.uns.ac.id
}

\begin{abstract}
Abstrak
Usaha peternakan merupakan salah satu sektor penyokong perekonomian Indonesia. Dalam menjalankan usaha peternakan dibutuhkan pakan yang berkualitas sehingga dihasilkan ternak yang berkualitas pula. Sekitar 70-80\% dari biaya total untuk pengelolaan peternakan dibutuhkan untuk pakan, sehingga perlu adanya inovasi untuk memformulasikan pakan sehingga mampu menekan biaya yang dibutuhkan peternak dan meningkatkan pendapatan. Tujuan dari penelitian ini adalah memperoleh pakan yang diformulasikan dengan ampas ekstraksi dengan sifat fisik yang memenuhi standar dan kandungan nutrisi yang sesuai. Hasil yang diperoleh menunjukan bahwa pakan masih memiliki kelembaban yang tinggi, akan tetapi memiliki kandungan energi total dan protein yang tinggi.
\end{abstract}

Kata Kunci : residu, kulit manggis, feed additive, pakan, kandungan nutrisi

\begin{abstract}
Farm is one of the supporting sectors of the Indonesian economy. In carrying out farm, quality feed required to produce quality livestock. Approximately 70-80\% of the total cost required to feed livestock management, so the need for innovation to formulate feed so as to reduce the cost required farmers and increase revenue. The outcome of this study was to obtain formulated feed with the residual extraction of Garcinia mangostana $L$ with physical properties that meet the standards and nutrient content accordingly. The results showed that feed still has a high humidity, but has a total high total energy and protein.
\end{abstract}

Keywords: feed additive, nutrition content, mangosteen

\section{Pendahuluan}

Salah satu pendukung perekonomian di Indonesia adalah sektor peternakan sehingga keberlangsungan usaha ternak termasuk ternak ayam perlu diperhatikan. Untuk mendukung keberlangsungan usaha ternak yang unggul, peternak membutuhkan kualitas pakan yang baik. Pakan yang memenuhi nutrisi hewan ternak dapat meningkatkan kualitas maupun kuantitas hasil ternak. Maka dari itu, dianjurkan untuk memenuhi nutrisi harian hewan ternak sesuai dengan kebutuhannya (Kusnandar B.A, 2004). Faktor gizi dan faktor ekonomis juga perlu diperhatikan dalam pemilihan komponen pakan sehingga hewan ternak mendapatkan pakan yang berkualitas baik (Erniasih and Saraswati, 2006).

Biaya pengelolaan peternakan terbesar yaitu 70\%-80\% merupakan biaya untuk pemenuhan pakan ternak. Biaya yang besar menuntut para peternak ayam dapat melakukan inovasi untuk menekan biaya sehingga mampu menaikan pendapatan. Inovasi yang dapat dilakukan berupa penyusunan formula pakan ayam sehingga diperoleh harga pakan yang murah tanpa mengabaikan faktor nutrisi ternak (Hidayat. S dan Mukhlas. I. 2015)

Industri obat tradisional merupakan tempat dilakukannya proses produksi obat tradisional dengan system pengawasan sesuai peraturan yang telah ditetapkan oleh pemerintah. Bahan baku yang digunakan dalam proses produksi berupa simplisia atau tanaman yang berkhasiat obat. Sebagai salah satu hasil akhir tak terpakai dari proses produksi adalah limbah atau amapas dari proses ekstraksi.

Produk dari bahan baku kulit buah manggis (Garcinia Mangostana L.) merupakan salah satu obat tradisional yang sedang berkembang pada dewasa ini. Kulit buah manggis mengandung banyak metabolit sekunder diantaranya senyawa golongan alkaloid, triterpenoid, saponin, flavonoid, tannin dan polifenol. Seperti yang telah dibuktikan oleh beberapa peneliti lain kulit buah manggis memiliki aktivitas farmakologi sebagai antikanker, antioksidan, antialergi, antibakteri, anti-inflamasi, antifungi, antivirus, serta anti malaria (Abubakeer et al., 2015; Chaverri et al., 2008; Miksusanti et al, 2012). Kulit 
buah manggis di ekstraksi menggunakan air untuk dibuat menjadi obat tradisional, residu yang dihasilkan memungkinkan masih adanya kandungan nutrisi yang masih dapat dimanfaatkan kembali. Tujuan dari penelitian ini adalah menemukan inovasi baru pada pakan ayam dengan memanfaatkan residu dari ekstraksi kulit buah manggis serta analisis kandungan nutrisi pakan, limbah diambil dari industry obat tradisional.

\section{Bahan Dan Metode}

Penelitian dilakukan di Laboratorium Farmasetika Prodi Farmasi FMIPA Universitas Sebelas Maret dan PT Saraswanti Indo Genetech Bogor untuk pengujian sifat fisik dan analisis kandungan nutrisi pakan.

\section{Bahan dan alat}

Dalam penelitian ini digunakan bahan percobaan berupa ampas dari hasil ekstraksi kulit manggis yang diperoleh dari CV Naturafit Thibbunnabawi Sragen, tepung jagung , tepung tapioka, bekatul, tepung kedelai, tepung ikan, minyak kelapa, kapur, DL-Methionin , Premix dan aquades. Alat-alat yang digunakan meliputi neraca, pisau, ayakan 100 , oven, cawan uap, waterbath, blender, stopwatch, dan alat-alat gelas (Pyrex Iwaki®).

\section{Cara kerja}

a. Pengeringan ampas kulit manggis

Ampas kulit manggis yang diperoleh dari hasil ekstraksi dikumpulkan dan dikeringkan di dalam oven dengan suhu $70^{\circ}$ C. Setelah kering (kadar air < 10\%), ampas sisa ekstraksi kulit manggis dihaluskan kembali agar mudah untuk diformulasikan dengan bahan yang lain.

b. Formulasi pakan

Semua bahan yang tertera pada formula tabel 1 dicampur dalam wadah kemudian di aduk homogen hingga membentuk suatu massa yang lunak. Massa yang diperoleh diayak menggunakan ayakan 10 hingga membentuk granul basah. Granul yang diperoleh di keringkan dalam oven suhu $60-70^{\circ} \mathrm{C}$ sampai berat konstan.

Tabel 1. Formula pakan dengan ampas kulit manggis termodifikasi (Muhammad et al., 2014).

\begin{tabular}{lrrr}
\hline \multicolumn{1}{c}{ Bahan } & F1 & F2 & F3 \\
\cline { 2 - 4 } Tepung Jagung & \multicolumn{3}{c}{ Persentas (\%) } \\
Tepung Tapioka & 43 & 43 & 43 \\
Bekatul & 7.5 & 7.5 & 7.5 \\
Bungkil Kedelai & 14.85 & 4.85 & 24.85 \\
Tepung Ikan & 15 & 15 & 15 \\
Minyak Kelapa & 6 & 6 & 6 \\
CaCo3 & 2 & 2 & 2 \\
DL-Methionin & 1.3 & 1.3 & 1.3 \\
\hline
\end{tabular}

\begin{tabular}{lrrr}
\hline Premix & 0.25 & 0.25 & 0.25 \\
Ampas kulit manggis & 10 & 20 & 0 \\
Aqua qs ad & 100 & 100 & 100 \\
\hline
\end{tabular}

c. Pengujian

Analisa kadar air pada pakan

Analisa kadar air pada pakan dilakukan dengan pengukuran kadar air yang hilang selama proses pengeringan (LOD) dan kandungan lembab dalam granul (MC). Susut pengeringan dari granul dapat dilakukan dengan penimbangan saksama seluruh granul basah yang sudah diayak kemudian keringkan pada suhu $40^{\circ} \mathrm{C}$.

LOD $=\underline{\text { berat basah- berat kering }} \times 100 \%$ berat sampel basah

$\mathrm{MC}=$ berat basah- berat kering $\times 100 \%$ berat sampel kering

Kandungan Nutrisi

Pengujian nutrisi pakan meliputi uji kandungan energy total, lemak total, protein, kalsium, serat kasar dan berat jenis dilakukan di PT Saraswanti Indo Genetech Bogor.

\section{Hasil dan Pembahasan}

Berdasarkan proses pembuatan yang dilakukan, pakan diformulasikan dalam bentuk granul. Proses granulasi dilakukan dengan metode granulasi basah. Granul yang telah dibuat dikeringkan pada suhu $50^{\circ}-60^{\circ} \mathrm{C}$ pada lemari pengering. Setelah diperoleh granul kering maka dilakukan pengujian LOD, MC dan kandungan nutrisi.

a. Analisa kandungan nutrisi pakan ayam

Tabel 2. Hasil Pengujian kandungan nutrisi

\begin{tabular}{llll} 
Parameter & F1 & F2 & F3 \\
\hline $\begin{array}{l}\text { Energi Total } \\
\text { (kkal/ Kg) }\end{array}$ & 3955.0 & 3891.0 & 3995.5 \\
$\begin{array}{l}\text { Lemak Total (\%) } \\
\text { Protein (\%) }\end{array}$ & 8.46 & 7.58 & 10.07 \\
Kalsium & 13.2 & 12.69 & 15.40 \\
(mg/100g) & 886.47 & 860.57 & 66.66 \\
Serat Kasar (\%) & 5.6 & 8.47 & 1.82 \\
Berat jenis (g/ml) & 0.5581 & 0.4902 & 0.6032 \\
\hline
\end{tabular}

Menurut Scott et.al (1982) kebutuhan energi termetabolis ayam tipe ringan umur 2-8 minggu antara 2600-3100 kkal/Kg dan protein pakan antara $18 \%$ 21,4\%. Sedangkan menurut NRC (1994) kebutuhan energi termetabolis dan protein masing-masing 2900 $\mathrm{kkal} / \mathrm{Kg}$ dan $18 \%$. Sementara menurut Alex (2011) kebutuhan protein untuk ayam kampung periode pertumbuhan sebesar 14\%-16\% dan energi berkisar 2600-2900 kkal/Kg. Hasil pengujian kandungan nutrisi dari pakan pada semua formula, mempunyai nilai parameter yang hampir sama. Berdasarkan uraian dan tabel 2 diperoleh data bahwa energi pada formula pakan dengan ampas sisa ekstraksi kulit manggis pada formula 1,2 dan 3 lebih tinggi daripada nilai yang ditetapkan. Hal ini lebih menguntungkan karena dengan nilai energi yang tinggi maka penggunaan 
pakan dapat dikurangi untuk mencapai nilai yang dibutuhkan oleh ayam ternak. Kebutuhan pakan yang berkurang akan menurunkan biaya pakan, namun memperoleh kualitas ternak yang sama baik sehingga peternak dapat meningkatkan pendapatannya. Dalam pemenuhan kebutuhan protein formula 3 pada pakan telah memenuhi standar untuk pakan ayam kampung namun belum memenuhi standar pakan untuk ayam ras.

b. Analisa kadar air pada pakan

Analisa kadar air pada granul pakan ayam dilakukan dengan penetapan LOD dan MC. Hasil pengujian LOD (Lost on Drying) dan MC (Moisture content) tertera pada tabel 3 ,

Tabel 3. Hasil pengujian sifat fisik pakan

\begin{tabular}{llll}
\hline \multicolumn{1}{c}{ Formula } & \multicolumn{1}{c}{ F1 } & \multicolumn{1}{c}{ F2 } & F3 \\
\hline Berat Basah (g) & 685 & 695 & 665,5 \\
Berat Kering (g) & 446,7 & 456,8 & 453,5 \\
LOD (\%) & 34,79 & 34,27 & 31,86 \\
MC (\%) & 49,96 & 52,15 & 46,75 \\
\hline
\end{tabular}

Kelembaban didalam zat padat dinyatakan dengan susut saat pengeringan disebut juga LOD (Lost on Drying) dan kandungan lembab disebut juga MC (Moisture content) (Lachman and Lachman, 1994). Menurut Badan Standadisasi Nasional (BSN) tahun 2006 kadar air dalam pakan maksimal 14\%. Hasil analisa data terhadap sifat fisik dari pakan menunjukkan bahwa semua formula masih menunjukkan kandungan lembab yang masih tinggi yaitu $>14 \%$. Kandungan lembab yang tinggi akan mengurangi kualitas dari pakan karena kondisi lembab akan meningkatkan pertumbuhan jamur (Sapri et al., 2012). Dalam mengatasi kandungan air yang masih cukup tinggi dapat dilakukan pengeringan kembali sehingga diperoleh hasil yang diinginkan.

\section{Kesimpulan}

Pakan dibuat dengan memanfaatkan residu sisa hasil ekstrasi kulit buah manggis pada industri obat tradisional memiliki potensi baik apabila dikembangkan sebagai pakan, sekaligus dapat mengurangi penumpukan limbah. Hasil pengujian kandungan nutrisi dari semua formula tidak jauh berbeda. Pakan yang dihasilkan masih memiliki kelembaban yang tinggi, akan tetapi memiliki kandungan energi total dan protein yang tinggi. Energi dan protein yang dihasilkan memungkinkan untuk dikembangkan dalam penelitian lanjutan.

\section{Saran}

Perlu dilakukan pengembangan formula pakan untuk mandapatkan kandungan nutrisi yang sesuai serta pengujian pada ternak untuk mengukur produktivitasnya.

\section{Ucapan Terimakasih}

Ucapan terimakasih tim pengabdi kepada Kemenristekdikti atas hibah pengabdian dengan skema IbM, Universitas Sebelas Maret dan CV
Naturafit Thibbunnabawi Sragen sebagai mitra dalam pengabdian

\section{Daftar Pustaka}

Abubakeer,A.M.A., Winarsih,S., Sujuti,H. (2015). Effect of Crude Ethanolic Extract of Mangosteen Pericarp (Garcinia mangostana Linn.) on IFN- $\gamma$ and IL12 Level in Mice Infected by Salmonella Typhimurium. International Journal of PharmTech Research.; Vol 8 No5: 996-1001

Alex, M.S. (2011). Pasti Untung Bisnis Ayam Kampung dalam waktu 6 minggu. Yogyakarta : Pustaka Baru press.

Chaverri, J. P., N. C. Rodriguez, M. O. Ibarra, and J. M. P. Rojas. (2008). Medicinal Properties of Mangosteen (Garcinia mangostana). Food and Chem. Toxicol., 46: 3227-3239.

Erniasih, I dan Saraswati T.R. (2006). Penambahan Limbah Padat Kunyit (Curcuma Domestica) pada Ransum Ayam dan Pengaruhnya terhadap Status Darah dan Hepar Ayam (Gallus sp), Buletin Anatomi dan Fisiologi.; Vol. XIV, No.2

Hidayat. S dan Mukhlas. I. (2015). Rancangan Bvangun dan Implementasi Sistem Pendukung Keputusan Berbasis Web untuk Menentukan Formulasi Ransum Pakan Ternak. Jurnal Sains dan Seni ITS. 4(2): 2337-3520.

Kusnandar, B.A. (2004). Aplikasi Program Linear dengan Microsoft Visual Basic 6.0 Dalam Formulasi Ransum Unggas. Tugas Akhir, Program Studi Nutrisi dan Makanan Ternak IPB.

Lachman L, Lieberman HA, Kanig JL. (1994). Teori dan Praktek Farmasi Indrustri. Edisi Ketiga. Vol III. Diterjemahkan oleh Siti Suyatmi. Jakarta: UI Press

Miksusanti, Elfita, dan Hotdelina S. (2012). Aktivitas Antioksidan dan Sifat Kestabilan Warna Campuran Ekstrak Etil Asetat Kulit Buah Manggis (Garcinia mangostana L.) dan Kayu Secang (Caesalpinia sappan L.). Jurnal Penelitian Sains.; Vol 15 No2( C)

Muhammad, N., Sahara, E., Sandi, S., Yosi, F., (2014). Pemberian Ransum Komplit Berbasis Bahan Baku Lokal Fermentasi terhadap Konsumsi, Pertambahan Bobot Badan, dan Berat Telur Itik Lokal Sumatera Selatan. J. Peternak. Sriwij. 3

NRC (National Research Council).(1994). Nutrient Requairement of puoltry. Eight revised. National Academy press, washington D.C. 
Sapri, S., Setiawan, D., Khairunnisa, R., (2012). Pengaruh Penggunaan Pati Biji Cempedak (Arthocarpus champeden Lour) Sebagai Bahan Pengikat Terhadap Sifat Fisik Tablet Parasetamol Secara Granulasi Basah. J. Trop. Pharm. Chem. 2.

Scott, M.L, M.C, Neisheim and R,J Young. (1982). Nutrition of Chicken 3rd edition M,L scott and associate: Ithaca, New York 